\title{
Studi Hasil Running Model Arus Permukaan Dengan Software Numerik Mike 21/3 (Guna Penentuan Lokasi Penempatan Stasiun Energi Arus Selat Lombok-Nusapenida)
}

\author{
Okol Sri Suharyo ${ }^{1}$, Dian Adrianto ${ }^{2}$ \\ ${ }^{1}$ Sekolah Tinggi Teknologi Angkatan Laut Surabaya \\ ${ }^{2}$ Pusat Hidro-Oseanografi TNI AL \\ E-mail: okolsrisuharyo@sttal.ac.id
}

\begin{abstract}
Abstrak
Untuk kepentingan penentuan lokasi penempatan energi listrik berbasis energi arus di sekitar Selat Lombok-Pulau Nusapenida diperlukan kajian awal terhadap bakal lokasi berupa parameter metode yang meliputi kondisi kedalaman, pasang surut dan arus serta parameter geografis kemasyarakatan yang meliputi kondisi sosial kemasyarakatan sekitar lokasi guna pemenuhan aktifitas pembangunan, monitoring dan pemeliharaan. Kajian parameter metode dilakukan dengan membuat simulasi model numerik dengan menggunakan Marine Modelling System Mike 21/3 yang dibuat dengan domain model area selat Lombok dan domain kajian sekitar P. Nusapenida dengan pembangkit pasang surut, yang di validasi dengan data arus. Untuk keperluan input model dan validasi digunakan peta Bathymetri terbitan Dishidros TNI AL no 29/2008 dan 262/2005, data pasang surut tanggal 22Juni - 19Juli 2016 dan data arus permukaan 23 Juni 22 Juli 2016. Kajian parameter geografis kemasyarakatan dilakukan dengan bantuan peta google earth untuk mengetahui kondisi geografi serta lokasi pemukiman dekat tempat lokasi alat. Keluaran dari kajian yang dilakukan berupa rekomendasi lokasi alternatif alat yang paling mungkin berdasarkan kajian dua parameter di atas yaitu direkomendasikan bahwa lokasi yang paling tepat adalah pada lokasi perairan antara Pulau Nusapenida dan pulau Ceningan.
\end{abstract}

Kata Kunci: Model Arus Numerik Mike, Energi Arus, Selat Lombok - Pulau Nusapenida

\section{PENDAhUluan}

Pesatnya perkembangan teknologi komputer sampai saat ini sangat mempermudah komunitas modeler numeric dalam membuat simulasi model berbasis numeric. Dengan adanya simulasi model dalam hal ini model hidrodinamika (arus), user dapat memperoleh gambaran terhadap pola pergerakan arus dalam suatu area dua dimensi maupun ruang/volume tiga dimensi. Simulasi model ini juga membantu untuk memahami pergerakan arus pada suatau ara walaupun dat pengukuran hanya pada single poin atau lebih

Mike zero adalah nama yang umum digunakan oleh salah satu software marine modelling system yang berbasis numeric. Dalam software mike dimana terdapat banyak modul yang dapat digunakan untuk membuat model arus, gelombang, sedimentasi baik di lautan, area pantai, sungai danau serta area lain sesuai kebutuhan pembuatan model. Sesuai seting model pada umunya desain model dalam hal ini luasan model, pembentukan mesh atau jaringan, input data yang dipergunakan serta adanya data validasi saangatlah mempengaruhi kestabilan dan akurasi model yang dibuat, sehingga semakin realistis. Untuk pembentukan mesh sendiri dalam mike 21/3 menggunakan flexible mesh berbasis finite element, hal ini sangat menguntungkan untuk mengatasai pembentukan mesh di area-area yang sulit yang mempunyai bentuk geometri antara lain, curam, berkelok-kelok, sempit dan lain sebagainya. Dengan demikian pembentukan mesh juga sangat menentukan dalam hasil model. 
Pada paper ini model arus permukaan yang termasuk pada modul Flow FM dipergunakan untuk membantu mengetahui pola pergerakan arus guna kepentingan pemilihan lokasi penempatan alat pembangkit litrik tenaga arus di sekitar perairan kepulauan Nusapenida.

\section{STUDI LITERATUR}

Penelitian di selat Lombok tentang dinamika arus permukaan telah banyak dilakukan, Priyana (1994) dan Miharja (2004) dalam studinya menyatakan bahwa selat Lombok merupakan tempat pertemuan dari 2 massa air dari Samudra Pasifik dan Samudra Indonesia memiliki karakteristik parameter fisis yang berubah terhadap musim, dengan parameter temperatur lebih dominan mempengaruhi pola sebaran kecepatan akustiknya dibandingkan dengan parameter fisis yang lain, seperti salinitas dan kedalaman. Diposaptono (2007) dalam penelitiannya menyampaian secara umum perubahan musim menimbulkan perubahan pola sebaran temperatur secara horisontal dimana lapisan permukaan memiliki harga paling tinggi pada musim Barat dan paling rendah pada musim Timur. Berbagai penelitian tentang pola arus laut permukaan di lokasi lain juga telah banyak dilakukan diantaranya adalah LPPM ITS - ICEES (2014) dalam studinya tentang Analysis Sedimentation Rate Due To Reclamation Plan in Segendis Bay Bontang. Penelitian selanjutnya studi tentang Wave Height Significant Modeling Due To Breakwater with BOUSS 2D oleh Tim LPPM ITS (2014), Coastal Modeling, Wave Modeling and Sediment Transport in Pelabuhan Perikanan Camplong Madura oleh Tim LPPM ITS (2015), Coastal Modeling - Feasibility Study Smelter \& Port Banyuwangi oleh Tim LPPM ITS (2015), Coastal Modeling - Sediment Transport in PLN Channel Tanjung Awar - Awar Tuban oleh tim LPPM ITS (2015), Coastal Modeling - study potential of ocean current power station in the strait Toyapakeh Nusa Penida Bali Tim LPPM ITS (2015), selanjutnya Coastal Modeling - study potential of ocean current power station in the strait Buton Sulawesi oleh Pusat Study Kelautan ITS (2015). Gap penelitian yang ada pada penelitian sebelumnya dibandingkan dengan penelitian ini adalah adanya pengembangan pemodelan arus permukaan dengan Model Numerik Mike 21 pada arus laut selat lombok dan perairan sekitar pulau Nusapenida untuk menentukan penempatan sumber energi berbasis arus laut permukaan yang belum pernah diteliti oleh peneliti-peneliti sebelumnya.

a. Proses Terjadinya Arus Laut

Menurut Pond dan Pickard (1983), arus terjadi karena adanya proses pergerakan massa air menuju kesetimbangan yang menyebabkan perpindahan horizontal dan vertikal massa air. Gerakan tersebut merupakan resultan dari Beberapa gaya yang bekerja dan beberapa factor yang mempengaruhinya. Arus laut (sea current) adalah gerakan massa air laut dari satu tempat ke tempat lain baik secara vertikal (gerak ke atas) maupun secara horizontal (gerakan ke samping). Contoh-contoh gerakan itu seperti gaya coriolis, yaitu gaya yang membelok arah arus dari tenaga rotasi bumi. Pembelokan itu akan mengarah ke kanan di belahan bumi utara dan mangarah ke kiri di belahan bumi selatan. Sedangkan menurut Gross (1990), arus merupakan gerakan horizontal atau vertikal dari massa air menuju kestabilan yang terjadi secara terus menerus. Gerakan yang terjadi merupakan hasil resultan dari berbagai macam gaya yang bekerja pada permukaan, kolom, dan dasar perairan. Hasil dari gerakan massa air adalah vector yang mempunyai besaran kecepatan dan arah.

b. Pasang Surut Air Laut

Menurut Pariwono (1989), fenomena pasang surut diartikan sebagai naik turunnya muka laut secara berkala akibat adanya gaya tarik benda-benda angkasa terutama matahari dan bulan terhadap massa air di bumi. Sedangkan menurut Dronkers (1964) pasang surut laut merupakan 
suatu fenomena pergerakan naik turunnya permukaan air laut secara berkala yang diakibatkan oleh kombinasi gaya gravitasi dan gaya tarik menarik dari benda-benda astronomi terutama oleh matahari, bumi dan bulan. Pengaruh benda angkasa lainnya dapat diabaikan karena jaraknya lebih jauh atau ukurannya lebih kecil.

US Research Project (1995) menyatakan pasang surut yang terjadi di bumi ada tiga jenis yaitu: pasang surut atmosfer (atmospheric tide), pasang surut laut (oceanic tide) dan pasang surut bumi padat (tide of the solid earth). Pasang surut laut merupakan hasil dari gaya tarik gravitasi dan efek sentrifugal. Efek sentrifugal adalah dorongan ke arah luar pusat rotasi. Gravitasi bervariasi secara langsung dengan massa tetapi berbanding terbalik terhadap jarak. Meskipun ukuran bulan lebih kecil dari matahari, gaya tarik gravitasi bulan dua kali lebih besar daripada gaya tarik matahari dalam membangkitkan pasang surutlaut karena jarak bulan lebih dekat daripada jarak matahari ke bumi. Gaya tarik gravitasi menarik airlaut ke arah bulan dan matahari dan menghasilkan dua tonjolan (bulge) pasang surut gravitasional dilaut. Lintang dari tonjolan pasang surut ditentukan oleh deklinasi, sudut antara sumbu rotasi bumi dan bidang orbital bulan dan matahari.

\section{METODOLOGI}

Lokus penelitian, Selat Lombok merupakan salah satu selat utama yang termasuk ALKI 2, dimana di sebelah Utara berbatasan dengan Laut Flores dan di sebelah Selatan berbatasan dengan Samudra Indonesia. Di sebelah Barat berbatasan dengan Pulau Bali dan Pulau Nusa Penida, dan di sebelah Timur berbatasan dengan Pulau Lombok. Panjang pintu masuk selat bagian Selatan antara Pulau Nusa Penida dengan Pulau Lombok sekitar $18 \mathrm{~km}$, dan bagian Utara sepanjang sekitar $40 \mathrm{~km}$. Panjang total Selat Lombok sekitar $60 \mathrm{~km}$. Pada umumnya kondisi bathymetri Selat Lombok landai, kecuali di tengah selat kondisi batimetri cukup curam sampai kedalaman $1000-1300 \mathrm{~m}$. Tempat terdalam terdapat di sebelah Selatan Pulau Nusa Penida antara 200 - 450 $\mathrm{m}$, dan di bagian ini terdapat sill yang sangat mempengaruhi dinamika oseanografi Selat Lombok (Supangat, 2003).

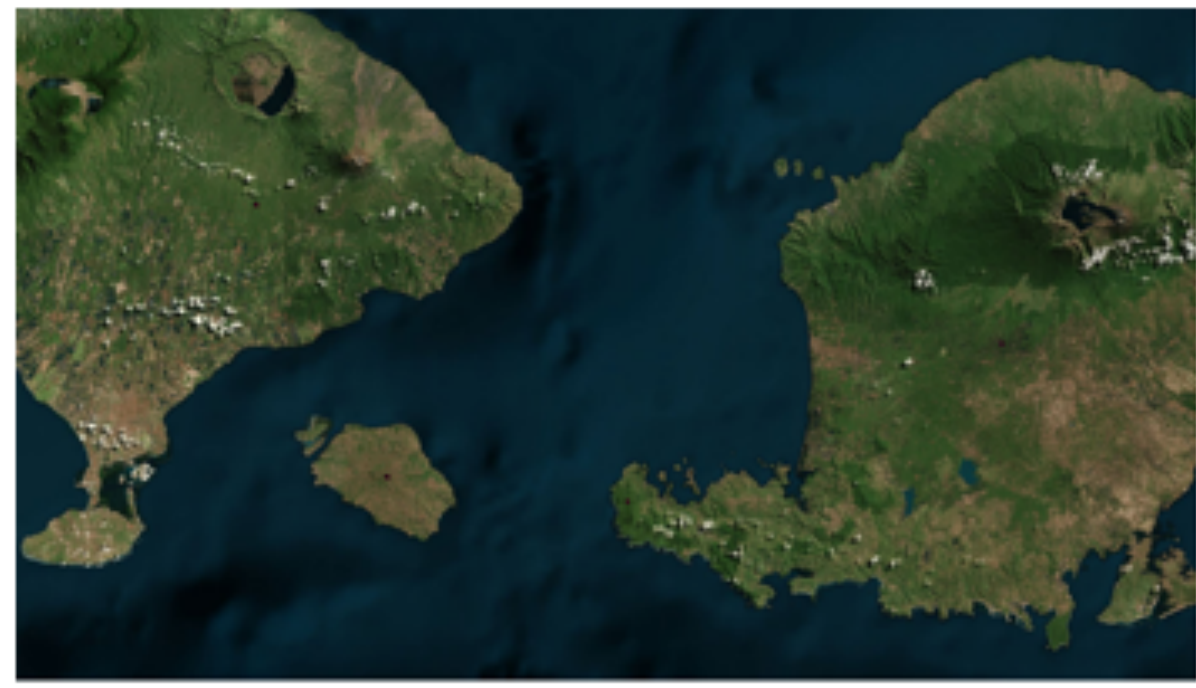

Gambar 26. Lokus Penelitian, Selat Lombok - P. Nusapenida

Selat Lombok terkenal juga sebagai tempat bertemunya dua massa air dalam jumlah besar, dari Samudra Pasifik dan Samudra Indonesia. Nilai temperatur (T) Samudra Pasifik lebih tinggi dibandingkan dari Samudra Indonesia, sedangkan nilai salinitas (S) Samudra Pasific lebih rendah 
dibandingkan dengan Samudra Indonesia (Wyrtki, 1961), seperti terlihat pada Gambar 2 di bawah ini:

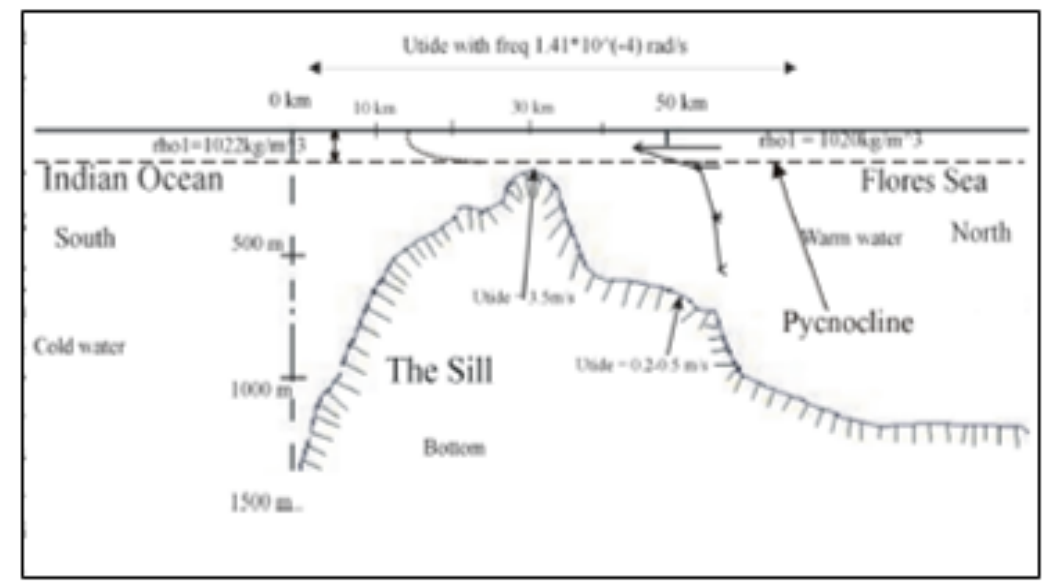

Gambar 27. Profil Melintang yang menunjukkan Sifat-Sifat Oseanografi di Selat Lombok.

(Sumber: Wyrtki, 1961)

\section{Pengumpulan dan Pengolahan Data}

Pengolahan data diawali dengan pengumpulan data yang dipergunakan sebagai input dalam kepentingan penentuan lokasi penempatan energi listrik berbasis energi arus. Untuk keperluan input model dan validasi digunakan peta bathymetri terbitan Dishidros TNI AL no 29/2008 dan 262/2005, data pasang surut tanggal 22Juni - 19Juli 2016 dan data arus permukaan 23 Juni - 22 Juli 2016 dari Laboratorium Hidrodinamika Fakultas Teknologi Kelautan ITS. Untuk melihat kelayakan model dilakukan verifikasi dg model yang dikembangkan di laboratorium Laboratorium Hidrodinamika Fakultas Teknologi Kelautan FTK-ITS dan Prodi S-2 ASRO STTAL.

\section{SIMULASI MODEL}

Simulasi dilakukan di selat Lombok sebagai domain model dan sekitar P.Nusapenida sebagai area kajian. Simulasi model ini menggunakan marine modeling system dengan modul Flow Model FM. Domain model dapat dilihat pada Gambar 3 dibawah ini yaitu yang berwarna merah dengan koordinat $05^{\circ} 02^{\prime} 00^{\prime \prime} 08^{\circ} 55^{\prime} 00^{\prime \prime} \mathrm{LS}$ dan $115^{\circ} 03^{\prime} 00^{\prime \prime}-115^{\circ} 30^{\prime} 00^{\prime \prime} \mathrm{BT}$. 


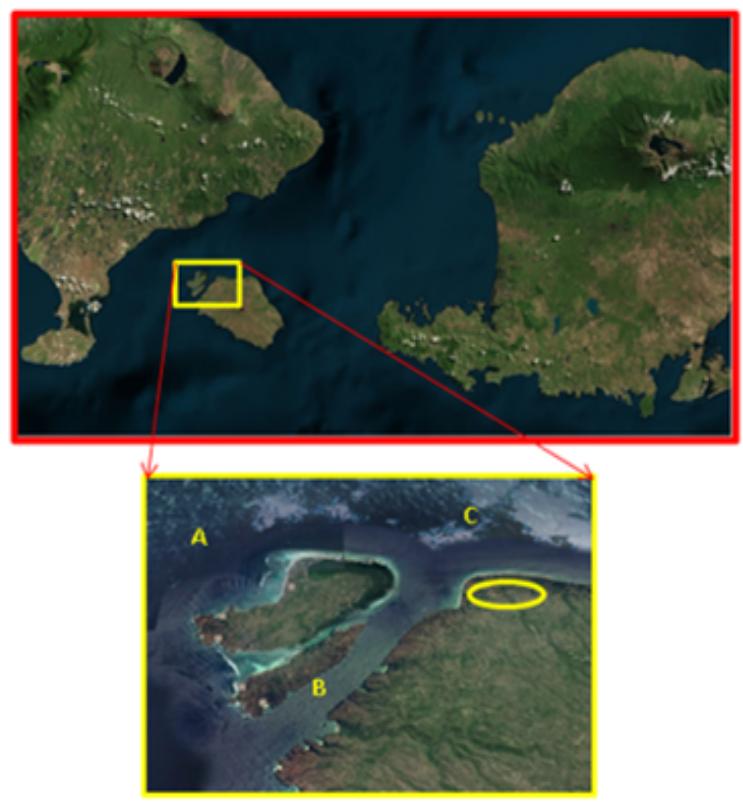

Gambar 28. Domain Model dan Area Kajian Tempat Bakal Lokasi Penempatan Alat.

Area yang berwarna kuning adalah area kajian yaitu daerah sekitar perairan Pulau Nusapenida tempat lokasi penempatan alat energy arus. Kemungkinan lokasi alat seperti terlihat pada huruf $\mathrm{A}$, B dan $\mathrm{C}$ sedangkan elips berwarna kuning merupakan tempat yang berpenduduk. Adapun datadata yang digunakan adalah data data bathymetri atau kedalaman yang diperoleh dari digitasi Peta Batimetri Dishidros TNI AL no peta 29 tahun 2008 dan peta 262 tahun 2005, Gambar 4 dibawah merupakan gambar dari peta yang digunakan sebagai input data kedalaman.

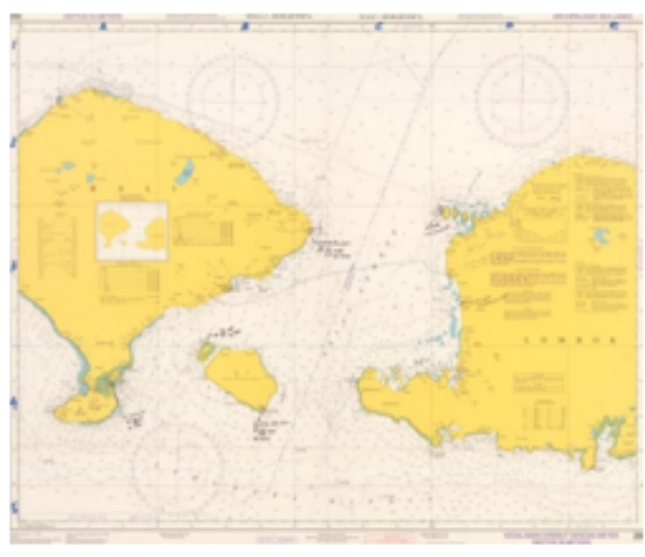

(a)

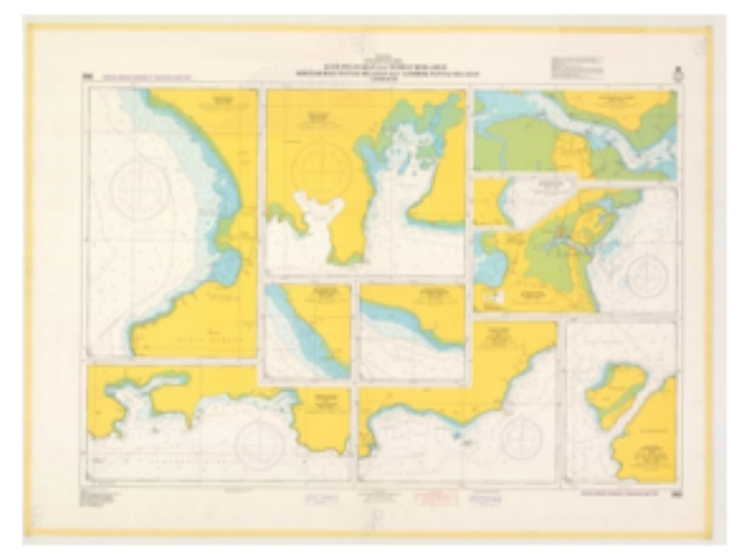

(b)

Gambar 29. Peta Bathimetri terbitan Dishidros TNI AL (a) Peta no 262 tahun 2005, (b) Peta no.29 tahun 2008.

Selanjutnya sebagai gaya pembangkit arus digunakan data pasang surut yang diperoleh dari Survei Dishidros TNI AL tahun 2016 yang dilakukan pengukuran pada posisi $08^{\circ} 43^{\prime} 44.99^{\prime \prime} \mathrm{S}$ $116^{\circ} 4^{\prime} 16.97^{\prime \prime} \mathrm{T}$, dengan lama pengamatan 29 hari mulai tanggal 22 Juni s/d 19 Juli 2016. Setelah melalui proses smoothing dan perhitungan metode Admiralty diperoleh konstanta harmonik dan grafik data arus dapat dilihat pada Gambar 5 dibawah ini. 


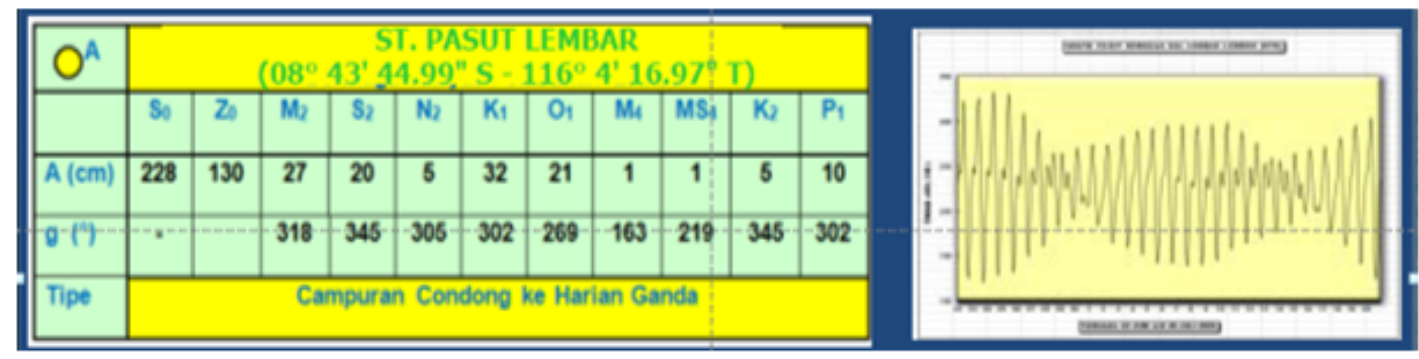

Gambar 30. Pasang surut lembar berdasar Survey Dihidros TNI AL tahun 2016

(a)Konstanta pasang surut, (b)Grafik pasang surut selama 29 hari.

Untuk validasi arus dipergunakan data arus pada survey yang sama yaitu data arus tanggal 23 Juni - 22 Juli 2016 pada posisi $08^{\circ} 43^{\prime} 19,9877^{\prime}$ S - 116 $03^{\prime} 23,6003^{\prime \prime} T$, selanjutnya data yang ada di smoothing dan dilakukan perhitungan komponen arus untuk mendapatkan konstanta arus dan pemisahan arus antara arus umum dan arus pang surut dan arus non pasut. Gambar 6 di bawah adalah Konstanta arus dan grafik arah dan kecepatan arus pasut dan non pasut.

\begin{tabular}{|c|c|c|c|c|c|c|c|c|c|c|}
\hline $0^{C}$ & \multicolumn{10}{|c|}{$\begin{array}{l}\text { ST. ARUS PERAIRAN PANTAI CEMARA LEMBAR } \\
\left(08^{\prime} 43^{\prime} 19,9877^{\prime \prime} S=116^{\prime} 03^{2} 23,6003^{\prime \prime} \mathrm{T}\right)\end{array}$} \\
\hline & $M_{2}$ & $\mathbf{S}_{2}$ & $\mathrm{~N}_{2}$ & $K_{4}$ & $\phi_{1}$ & $\mathrm{M}_{4}$ & $\mathrm{MS}_{4}$ & $\mathrm{~K}_{2}$ & $P_{1}$ & $\begin{array}{l}\text { ARAH } \\
\text { UTAMA }\end{array}$ \\
\hline $\bar{A}(\mathrm{~cm})$ & 0.013 & 0.005 & 0.004 & 0.013 & 0.004 & 0.004 & 0.006 & 0.002 & 0.003 & $62.47^{\circ}$ \\
\hline $8 \mathrm{Cl}$ & 61 & 18 & 150 & 34 & 67 & 98 & 1 & 25 & 34 & \\
\hline
\end{tabular}

(a)

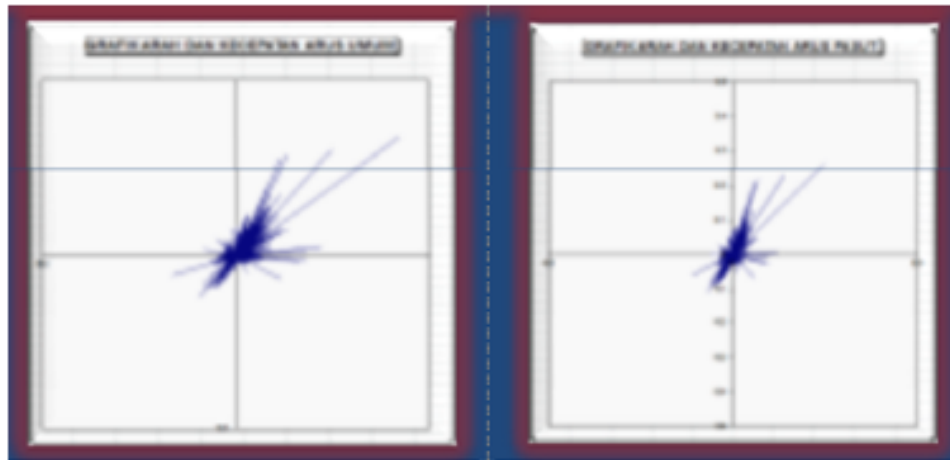

(b)

(c)

Gambar 31. Gambar Konstanta dan Grafik Arus Pasut (a) Konstanta Arus, (b) Grafik Arah dan Kecepatan Arus Pasut, (c) Grafik Arah dan Kecepatan Arus Non Pasut.

Simulasi model dilakukan diseluruh domain model selat Lombok untuk mengetahui arah dan kecepatan arus disekitar pulau nusapenida dan di running selama 1 bulan dengan time step 5 menit. Kajian parameter sosial kemasyarakatan dilakukan untuk mendukung analisa secara geografis demi kepentingan pembangunan alat, monitoring dan pemeliharaan. Untuk itu sebaiknya lokasi alat tidak terlalu jauh dengan komunitas penduduk terutama aktifitas pelayaran.dapat mengganggu system tersebut. Selain itu lokasi yang dengan medan yang sulit juga tidak diharapkan karena mempersulit proses aktifitas diatas.

\section{HASIL DAN ANALISA}

Salah satu hasil model yang telah dilakukan dapat dilihat pada Gambar 7 di bawah ini: 


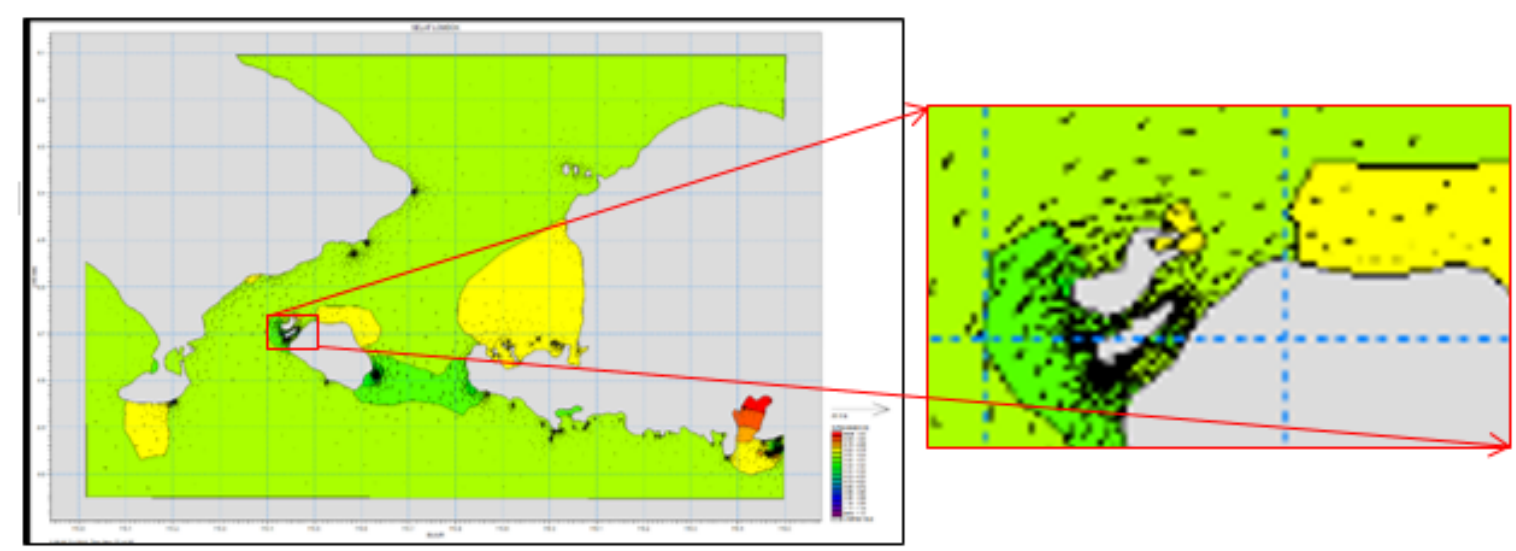

Gambar 32. Hasil Model Arus Saat Air Pasut menuju Surut

Gambar 7 di atas adalah hasil model yang yang menunjukkan waktu pasut menuju surut, dimana secara teoritis pada kondisi inilah kuat arus bernilai paling besar dibandingkan kondisi lainnya. Kuat arus terbesar terjadi pada saat air menuju surut pada saat spring tide. Dalam gambar tinggi elevasi air dapat dapat dilihat pada legenda warna sebelah kanan, dan tanda panah menunjukkan skala kuat arus dalam satuan meter perdetik.

Berdasarkan Gambar 7 dihubungkan dengan Gambar 3 di atas dimana diantara area A,B dan $\mathrm{C}$, terlihat bahwa arus lebih deras terjadi pada lokasi B dengan kuat arus berkisar antara $0.5-1$ $\mathrm{m} / \mathrm{s}$ atau $1-2$ knot, jika dibandingkan dengan lokasi pada A dan $\mathrm{C}$ yang bernilai lebih kecil. Sehingga berdasarkan hasil simulasi ini ara B merupakan prioritas pertama.

Selanjutnya dilakukan kajian gegrafis kemasyarakatan sesuai dengan gambar Gambar 8 di bawah ini:

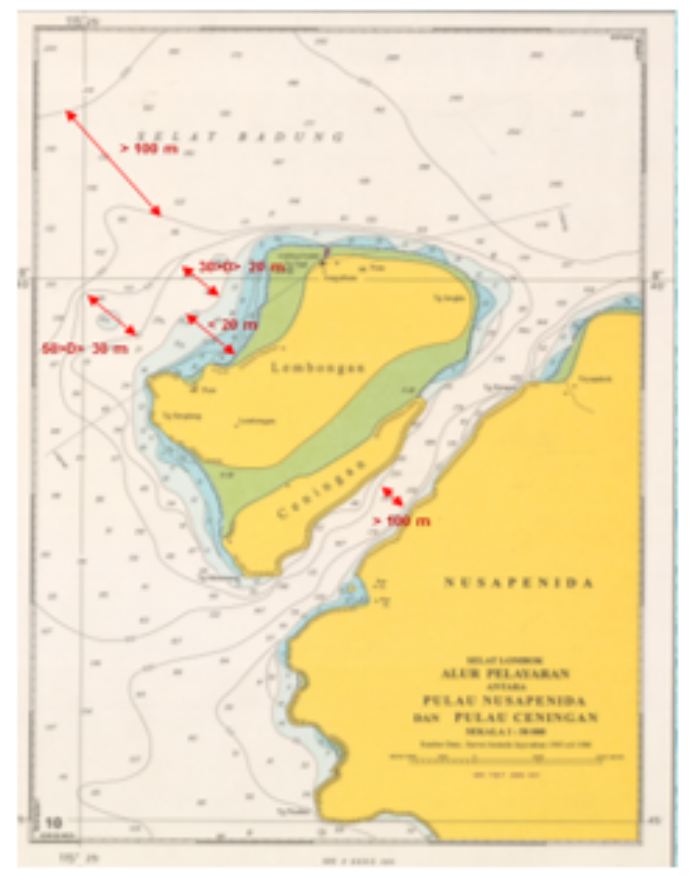

Gambar 33. Kondisi Perairan Sekitar Lokasi Kajian

Berdasarkan Gambar 8 di atas dan dihubungkan pada Gambar 3 dapat dilihat pada area B mempunyai kondisi dasar laut yang curam dibandingkan terutama pada lokasi A, sedangkan. Pada lokasi b kedalaman yang diperlukan yaitu kedalaman $10-50 \mathrm{~m}$ tidak terlalu jauh berkisar dari 
pantai dibandingkan pada A yang terlalu jauh berkisar 20 - $40 \mathrm{~m}$ dibandingkan pada lokasi A yang relative landau yaitu sekitar $1-2 \mathrm{~km}$ dari pantai, sedangkan lokasi $\mathrm{C}$ terlalu dalam di atas kedalaman $50 \mathrm{~m}$. Keunggulan lain bahwa didaerah B tidak langsung terletak di depan pemukiman masyarakat walupun juga tidak terlalu jauh dibandingkan dua lokasi lainnya. Oleh karena itu urutan prioritas penempatan alat stasiun energy berturut turtu adalah lokasi B, A dan C berdasarkan hasil moden dan analisa kondisi geografis daerah kajian.

\section{KESIMPULAN}

Simulasi dengan melakukan pemodelan numerik sangatlah membantu guna keperluan pemahaman tentang pola arus di suatu area tertentu. Disamping itu analisa kondisi geografis berdasarkan image yang diperoleh dari citra satelit ataupun survey di lapangan (peta) melengkapi kajian yang diperlukan. Berdasar analisa hasil simulasi numerik yang dilakukan serta analisa kondisi geografis perairan area kajian Selat Lombiok - Pulau Nusapenida untuk penentuan lokasi penempatan stasiun energy listrik berbasis energy arus laut dihasilkan rekomendasi tentang urutan prioritas lokasi penempatan tersebut yaitu pada lokasi B, A dan C.

\section{DAFTAR PUSTAKA}

[1] A. Defant. Ebb And Flow. The Tides of Earth, Air, and Water. Michigan: The University of Michigan Press. 1958.

[2] S. Diposaptono. Karakteristik Laut Pada Kota Pantai. Direktorat Bina Pesisir, Direktorat Jendral Urusan Pesisir dan Pulau-pulau Kecil. Jakarta: Departemen Kelautan dan Perikanan. 2007.

[3] J. J. Dronkers. Tidal Computations in rivers and coastal waters. Amsterdam: North-Holland Publishing Company. 1964.

[4] M.G. Gross. Oceanography; A View of Earth. Englewood Cliff. New Jersey: Prentice Hall, Inc. 1990.

[5] C. A. M. King. An Introduction to Oceanography. New York. San Francisco: McGraw Hill Book Company, Inc. 1996.

[6] C. D. H. Mac Millan. Tides. New York: American Elsevier Publishing Company, Inc. 1966.

[7] D.K. Miharja, S. Hadi dan M. Ali. Pasang Surut Laut. Kursus Intensive Oseanografi bagi perwira TNI AL. Lembaga Pengabdian masyarakat dan jurusan Geofisika dan Meteorologi. Bandung: Institut Teknologi Bandung. 2004.

[8] J. I. Pariwono. Gaya Penggerak Pasang Surut. Dalam Pasang Surut. Ed. Ongkosongo, O.S.R. dan Suyarso. P3O-LIPI. Jakarta. 1989. Hal. 13-23

[9] G. L. Pickard. Descriptive Physical Oceanography. Oxford: Pergamon Press. 1993.

[10] Pond dan Pickard. Introductory to Dynamic Oceanography. Oxford: Pergamon Press. 1978

[11] S. Pond dan G. L. Pickard. Introductory dynamical Oceanography. Second edition. New York: Pergamon Press. 1983.

[12] Priyana. Studi pola Arus Pasang Surut di Teluk Labuhantereng Lombok. Nusa Tenggara Barat. Skripsi. Bogor: Program Studi Ilmu dan Teknologi Kelautan, Fakultas Perikanan dan Kelautan, Institut Pertanian Bogor. 1994.

[13] K. Wyrtki. Phyical Oceanography of the South East Asian Waters. California: Naga Report Vol. 2 Scripps, Institute Oceanography. 1961.

[14] Lamona I. Bernawis. Temperature and Pressure Responses on El-Nino 1997 and La-Nina 1998 in Lombok Strait. Proc. The JSPS-DGHE International Symposium on Fisheries Science in

Tropical Area. 2000. 
Applied Technology and Computing Science Journal, Vol. 1, No. 1, June 2018.

[15] M. G. Gross. Oceanography: A View of Earth. Englewood Cliff. New Jersey: Prentice Hall, Inc. 1990.

[16] J. M. Bishop. 1984. Aplied Oceanography. New York: John Willey and Sons, Inc. 1984: 252. [17] M. Gross. 1990. Oceanography sixth edition. New Jersey: Prentice-Hall.Inc.

[18] A. Supangat dan Susanna. Pengantar Oseanografi, Pusat Riset wilayah Laut dan Sumberdaya Non-Hayati, BRPKP-DKP. ISBN. No. 979-97572-4-1. 2003.

[19] US Research project. NSF and Oregon State University. 1995. 